\title{
Promoting effects of 6-Gingerol on probiotic adhesion to colonic epithelial cells
}

\author{
Qian JIANG ${ }^{1}, \mathrm{Na} \mathrm{XU}^{1}$, Lingyan KONG${ }^{1}$, Mengxi WANG ${ }^{1}$, Hong $\mathrm{LEI}^{1 \star ~(1) ~}$
}

\begin{abstract}
The effects of 6-gingerol on adhesive ability of probiotics to colonic epithelial cells in vitro were explored. Two strains of probiotics were Lactophilus acidophilus and Bifidobacterium bifidum. NCM 460 cells (normal colonic epithelial cells) and Caco2 cells (colon cancer cells) were used in this study. Effect of 6 -gingerol $(5,10,15,20,25,30,35,40 \mu \mathrm{g} / \mathrm{mL}$ on NCM 460 cells and effect of 6-gingerol $(10,25,50,75,100,125,150,175 \mu \mathrm{g} / \mathrm{mL})$ on Caco-2 cells were investigated. MTT assay was adopted to analyze cell proliferation. Methods of Gram staining and plate counting were used to analyze the probiotic adhesion to colonic epithelial cells. Results showed that 6-gingerol had no inhibitory effect on colonic epithelial cells within the non-cytotoxic dose range. 6-gingerol could promote the adhesion of probiotics to colon epithelial cells in a dose-dependent manner, which would be benefit for probiotics to exert continuous probiotic activity in the intestinal tract.
\end{abstract}

Keywords: 6 - gingerol; probiotics; adhesive ability; colonic epithelial cells.

Practical Application: As the candidate of functional component for improving intestinal micro-ecosystem.

\section{Introduction}

Intestinal probiotics are mixture of microorganisms which have beneficial effects on the health of the host by adjusting balance of intestinal flora, including preventing the occurrence of intestinal inflammatory diseases and stimulating the beneficial effects of probiotics in the gut system (Huang et al., 2014). Several studies have demonstrated that probiotics could inhibit the growth of harmful bacteria and strengthen the intestinal mucosal barrier of host (Bao et al., 2010; Kotzamanidis et al., 2010; Vázquez-Fresno et al., 2014; Liu et al., 2016). Meanwhile, probiotic adhesion is an essential prerequisite for physiological functions of probiotics (Zhang, 2019; Li et al., 2011; Wang et al., 2019; Bai et al., 2012). So promoting the probiotic adhesion would strengthen the beneficial effects of probiotics. It has been reported that some natural foods and their extracts such as apple extracts (peel and pulp) and their phenolic constituents increased the adhesion of two probiotics strains to intestinal epithelial cells (Volstatova et al., 2017).

Gingerol is a kind of phenolic substance in ginger and 6-gingerol is the main functional components, which has been reported to have significant anti-inflammatory, anti-oxidant, anti-apoptotic effects, and to regulate blood sugar and blood lipids (Li et al., 2017; Choi et al., 2018; Rahmani et al., 2014). It has also been reported that the duration of 6-Gingerol compounds available in the colon was up to $12 \mathrm{~h}$, which may favor their antioxidant potential and healthy effects (Majdoub et al., 2019). Moreover, 6-gingerol could prevent DSS-induced chronic UC via anti-inflammatory and antioxidative mechanisms and preservation of the Wnt / $\beta$-catenin signaling pathway (Ajayi et al., 2018). 6-gingerol also improved ulceration and bleeding in the gastrointestinal tract caused by aspirin (Zhu et al., 2017). Therefore, 6-gingerol intervention has been reported to have beneficial effect on the health of colon.

It has been reported that treatment with ginger extracts promoted the adhesion ability of probiotics L. acidophilus and L. brevis to intestinal epithelial cells (Prakasita et al., 2019). While the effects the main active component 6-gingerol on the probiotics' adhesion to colonic cells were unknown. Colon tissues are the main sites where probiotics exert their effects and colitis is the major canal disease perplexing mankind. Therefore, the present study would explore the effects of 6-gingerol on the adhesion activity of probiotics (Lactophilus acidophilus and Bifidobacterium bifidum) to colonic epithelial cells (NCM460 cells and Caco-2 cells), which would provide the experimental basis for application of 6-gingerol as the candidate of functional component for improving intestinal health.

\section{Materials and methods}

\subsection{Materials}

Caco-2 cell line was purchased from the Key Laboratory of Dairy of Northeast Agricultural University. NCM460 cell line was purchased from Guangzhou Biotechnology Co., Ltd. Two strains of probiotics Lactophilus acidophilus (AS1.2686) 
and Bifidobacterium bifidum (CDMCCL-1.324) were purchased from Guangzhou Microbial Strain Collection Center.

Tween 80 (analytical grade) was from Sinopharm Chemical Reagent Co., Ltd. Serum was from Tianjin Ouyang Biological Products Technology Co., Ltd. Medium containing high sugar was from Thermo Fisher Scientific (Beijing) Co., Ltd. Penicillin solution (containing double antibody) was purchased from American Sigma Company; Trypsin was from Beijing Solibao Technology Co., Ltd. MRS broth medium, TPY liquid medium and Bifidobacterium bifidus BS medium were from Shanghai Bo Microbiology Technology Co., Ltd. MRS agar was from Technology Co., Ltd. PBS was from Gbico Corporation and MTT was from Beyotime Corporation.

\subsection{Effects of 6-gingerol on the growth of colonic epithelial cells}

The effect of 6-gingerol on growth of NCM460 cells and Caco- 2 cells by MTT assay were investigated. Colonic epithelial cells suspension $200 \mu \mathrm{L}$ with the concentration of $1 \times 10^{5} / \mathrm{mL}$ were inoculated into a 96-well cell culture plate. As the cells adhered to the plate wall for $24 \mathrm{~h}$, the cells were washed with sterile PBS. Then 6-gingerol with the concentration gradient and DMEM complete culture solution (containing 10\% fetal bovine serum) were added, and then were cultured in a $37^{\circ} \mathrm{C}, 5 \%$ $\mathrm{CO}_{2}$ cell incubator. After $24 \mathrm{~h}$ of incubation, the morphology of cells were observed under the microscope. Then $20 \mu \mathrm{L}$ of MTT solution $(5 \mathrm{mg} / \mathrm{mL})$ was added to each well and was incubated at $37^{\circ} \mathrm{Cfor} 4 \mathrm{~h}$. Absorbance (A) of each well at a wavelength of $570 \mathrm{~nm}$ was measured by the full-wavelength microplate reader. Cell inhibition rate was calculated. Cell inhibition rate $(\%)=\left(1-A_{1} / A_{0}\right) \times 100 \%$, Where $A_{1}$ is the average absorbance value of experimental group and $A_{0}$ is the average absorbance value of control group. The concentration of 6-Gingerol with the inhibition rate below $10 \%\left(\mathrm{IC}_{10}\right)$ was selected for the subsequent experiments.

\subsection{Preparation of probiotics suspension}

Bifidobacterium bifidum or Lactobacillus acidophilus was inoculated in the liquid medium and then cultured in an anaerobic box at $37^{\circ} \mathrm{C}$ for $48 \mathrm{~h}$. Then the bacterial were collected and were centrifuged at $4{ }^{\circ} \mathrm{C}, 4500 \mathrm{rpm}$ for $5 \mathrm{~min}$. The bacterial were washed three times with sterile PBS and were suspend in DMEM culture medium without serum and antibodies. The concentration of bacterial suspension was adjusted to $1 \times 10^{8} \mathrm{CFU} / \mathrm{ml}$.

\subsection{Effects of 6-gingerol on adhesive ability of probiotic with colonic epithelial cells}

The cells were inoculated into 6-well plates containing cell slides. The cells of control group were added with $2 \mathrm{~mL}$ of DMEM complete culture solution, and the cells of 3 treated groups were added with a certain concentration of 6 - Gingerol and DMEM complete medium. After the cells were cultured at $37^{\circ} \mathrm{C}$ in a $5 \% \mathrm{CO}_{2}$ incubator for $24 \mathrm{~h}$, the supernatant was discarded and each well was washed twice with PBS. Then the probiotic suspension $1 \mathrm{~mL}$ and DMEM culture medium $1 \mathrm{~mL}$ (without antibodies) were added to each well. The cells were incubated in incubator at $37^{\circ} \mathrm{C}, 5 \%$ $\mathrm{CO}_{2}$ atmosphere. After 1-2 h, the supernatant was discarded and washed for 5 times with PBS to remove non-adherent bacteria. Finally, bacteria were fixed with methanol for 30 min and were stained by Gram's method until naturally dried. The adhesion of probiotics was observed under the microscope (Liu et al., 2013).

\subsection{Effects of 6-gingerol on adhesion rate of probiotic with colonic epithelial cells}

Probiotics and cells were treated the same as above. Bacterial suspension was added directly to cells in a 6-well plate (without the slides). The cells were washed with PBS for 3 times, treated with trypsin and were counted. The average number of probiotics adherent to cells was calculated according to the following formula (Gopal et al., 2001). Adhesion number $(\mathrm{CFU} /$ cell $)=$ Number of adherent colonies in culture plate $/$ Number of cells in culture. Adhesion rate $(\%)=\left(\mathrm{N}_{1} / \mathrm{N}_{0}\right) \times 100 \%$, Where $\mathrm{N}_{1}$ is the number of colonies after adhesion and $\mathrm{N}_{0}$ is the number of colonies before adhesion.

\subsection{Statistical analysis}

Data were expressed as means \pm s.d. Statistical analysis was evaluated using SPSS 16.0 software by one-way analysis of variance, followed by the Student-Newman-Keuls test for multiple comparisons, which was used to evaluate the difference between two groups. $\mathrm{P}<0.05$ was considered significant.

\section{Results and discussion}

\subsection{Effects of 6-gingerol on the growth of NCM460 cells and Caco- 2 cells}

The effect of 6-gingerol on the growth of NCM460 cells and Caco- 2 cells and the inhibition rate were measured by

Table 1. Effects of 6-gingerol on the growth inhibition rate of NCM460 cells.

\begin{tabular}{cccc}
\hline Group & $\begin{array}{c}\text { Concentration } \\
(\mu \mathrm{g} / \mathrm{mL})\end{array}$ & $\begin{array}{c}\text { Absorbance } \\
(\mu \mathrm{x} \pm \mathrm{s})\end{array}$ & $\begin{array}{c}\text { Inhibition rate } \\
(\%)\end{array}$ \\
\hline Control group & - & $2.848 \pm 0.009$ & - \\
6-gingerol & 5 & $2.712 \pm 0.006^{\mathrm{a}}$ & 4.747 \\
& 10 & $2.679 \pm 0.016^{\mathrm{a}}$ & 5.903 \\
& 15 & $2.606 \pm 0.019^{\mathrm{a}}$ & 8.485 \\
& 20 & $2.567 \pm 0.013^{\mathrm{a}}$ & 9.856 \\
& 25 & $2.470 \pm 0.008^{\mathrm{a}}$ & 13.265 \\
& 30 & $2.346 \pm 0.011^{\mathrm{a}}$ & 17.628 \\
& 35 & $2.214 \pm 0.013^{\mathrm{a}}$ & 22.246 \\
& 40 & $2.074 \pm 0.099^{\mathrm{a}}$ & 27.153 \\
\hline
\end{tabular}

Compared with control group, ${ }^{\mathrm{a}} \mathrm{P}<0.05$ 
MTT method. The results were shown in Tables 1 and 2 . $\mathrm{IC}_{10}$ of 6-gingerol was the non-cytotoxic dose, which was the concentration of 6-gingerol whose inhibition rate was less

Table 2. Effects of 6-gingerol on the growth inhibition rate of Caco-2 cells.

\begin{tabular}{cccc}
\hline Group & $\begin{array}{c}\text { Concentration } \\
(\mu \mathrm{g} / \mathrm{mL})\end{array}$ & $\begin{array}{c}\text { Absorbance } \\
(\mu \mathrm{x} \pm \mathrm{s})\end{array}$ & $\begin{array}{c}\text { Inhibition } \\
\text { rate }(\%)\end{array}$ \\
\hline Control group & - & $2.227 \pm 0.017$ & - \\
6-gingerol & 10 & $2.178 \pm 0.079$ & 2.209 \\
& 25 & $2.156 \pm 0.012^{\mathrm{a}}$ & 3.181 \\
& 50 & $2.116 \pm 0.007^{\mathrm{a}}$ & 4.990 \\
& 75 & $2.096 \pm 0.089^{\mathrm{a}}$ & 5.871 \\
& 100 & $2.077 \pm 0.033^{\mathrm{a}}$ & 6.750 \\
& 125 & $2.048 \pm 0.16^{\mathrm{a}}$ & 8.062 \\
& 150 & $2.012 \pm 0.034^{\mathrm{a}}$ & 9.682 \\
& 175 & $1.960 \pm 0.087^{\mathrm{a}}$ & 11.977 \\
\hline
\end{tabular}

Compared with control group, $\mathrm{P}<0.05$.
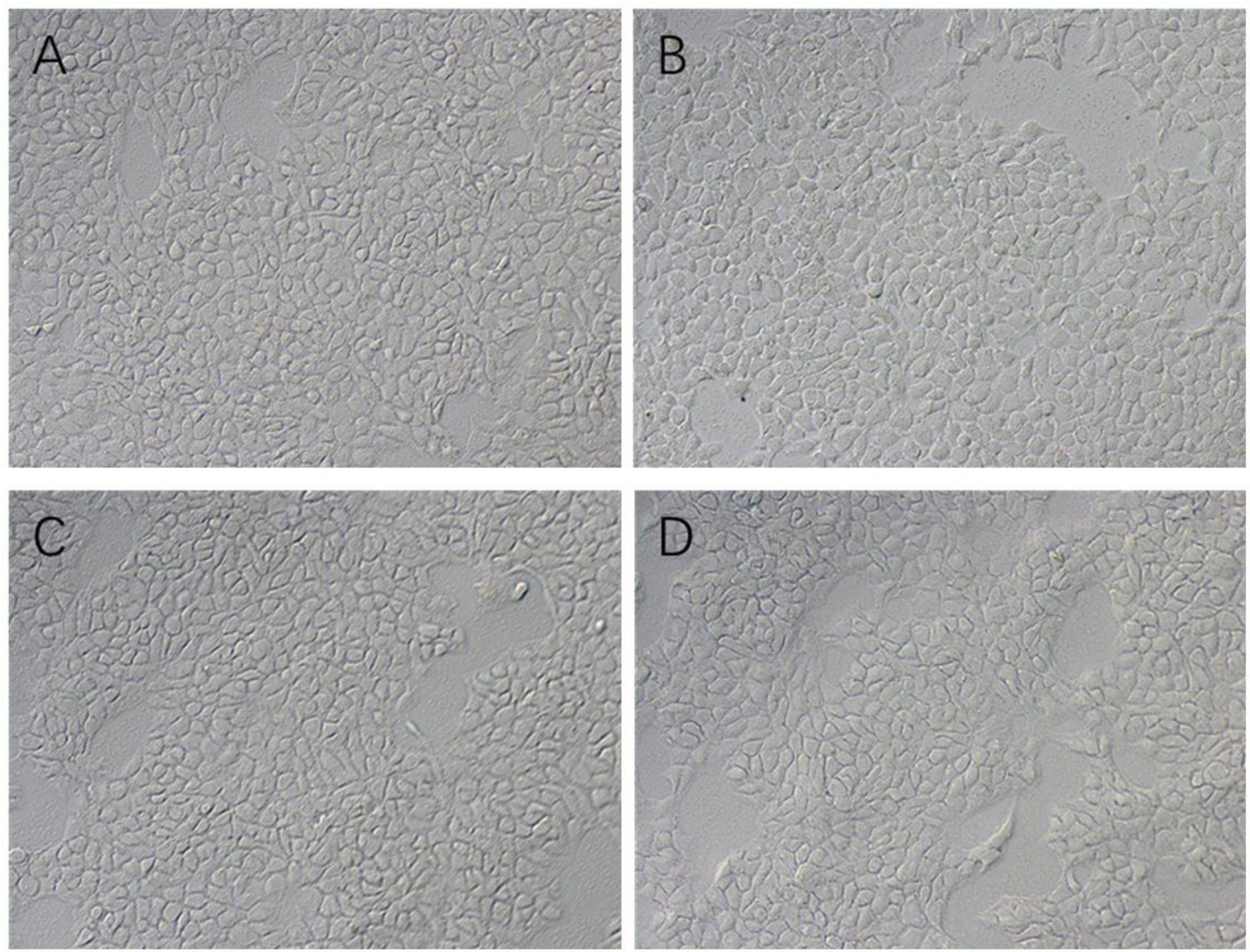

than $10 \%$. Addition of 6-gingerol at different concentrations significantly inhibited the proliferation of cells. With the on cell proliferation gradually increased in a dose-dependent manner. When the concentration of 6-gingerol was $\leq 20 \mu \mathrm{g} / \mathrm{mL}$, the inhibition rate of NCM460 cells was less than $10 \%$. When the concentration of 6-gingerol was $\leq 150 \mu \mathrm{g} / \mathrm{mL}$, the inhibition rate of Caco-2 cells was less than $10 \%$. After treated with the above range concentrations of 6 -gingerol for $24 \mathrm{~h}$, the cells were observed under microscope. Figure 1 and 2 showed that as the concentration of 6-gingerol was less than $\mathrm{IC}_{10}$, the cells adhered to the plate well and the status of cells were good.

According to the previously reported (Zhu et al., 2019), to investigate the effects of food products on the adhesion of intestinal probiotics, the foregoing cytotoxic experiments should be done to test the adverse effect of different concentration of the products on intestinal cells, and moreover, to select the appropriate working concentration of the products. increase of concentration of 6-gingerol, the inhibitory effect

Figure 1. Effects of different concentration of 6-gingerol on growth of NCM460 cells (200×). (A) Normal group; (B) 6-gingerol (5 $\mu \mathrm{g} / \mathrm{mL})$ group; (C) 6-gingerol $(10 \mu \mathrm{g} / \mathrm{mL})$ group; (D) 6-gingerol $(20 \mu \mathrm{g} / \mathrm{mL})$ group. 
Therefore, through the foregoing cytotoxic experiments, 6 -gingerol concentration of $5,10,20 \mu \mathrm{g} / \mathrm{mL}$ was used to treat NCM460 cells, and 6-gingerol concentration 50, 100, $150 \mu \mathrm{g} / \mathrm{mL}$ was used to treat Caco-2 cells for the subsequent experiments of probiotic adhesion.
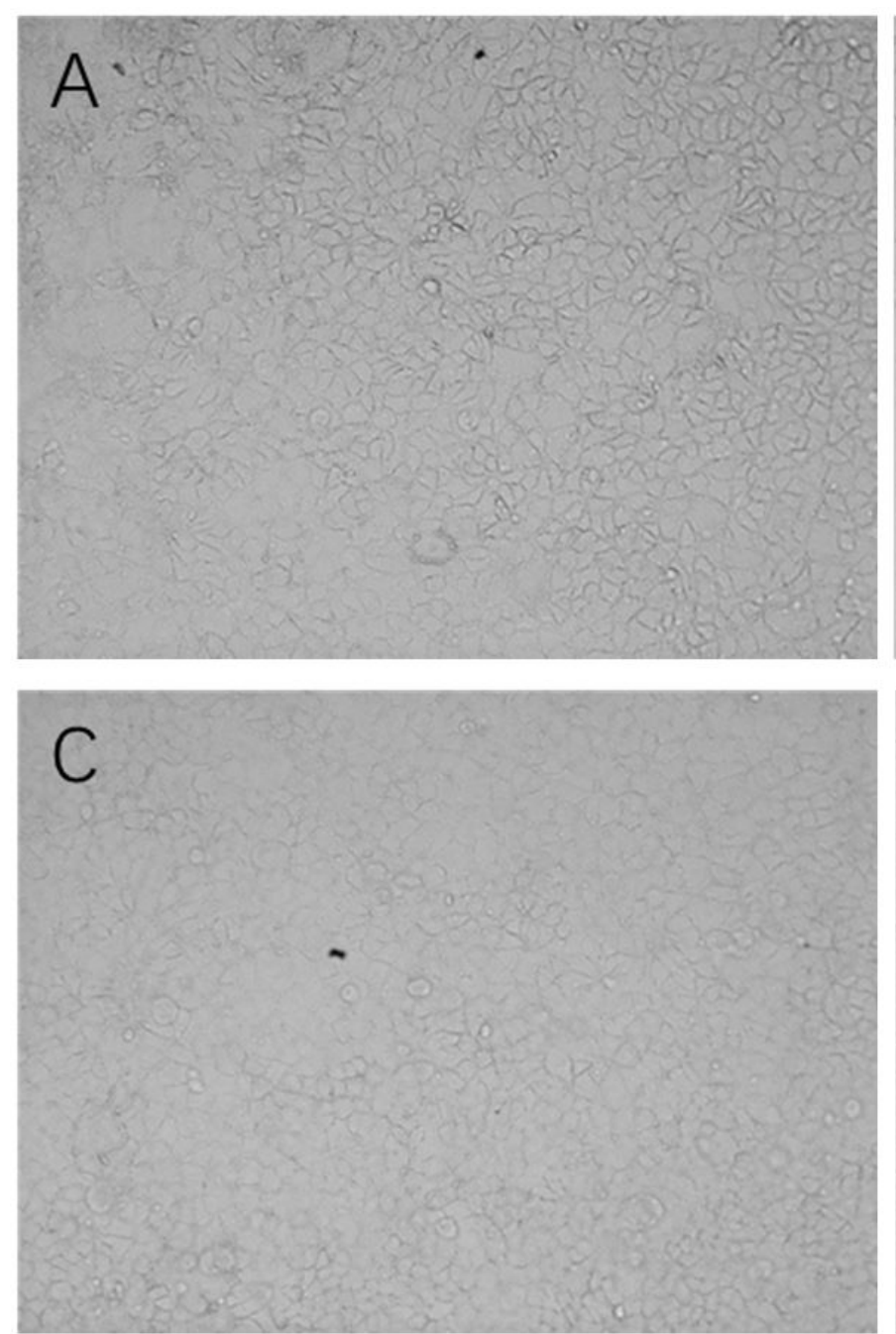

\subsection{Promotive effect of 6-gingerol on adhesion ability of probiotics with NCM460 cells}

Lactophilus acidophilus and Bifidobacterium bifidum are two kinds of important sources of probiotic strains. Compared with the normal control group, addition of
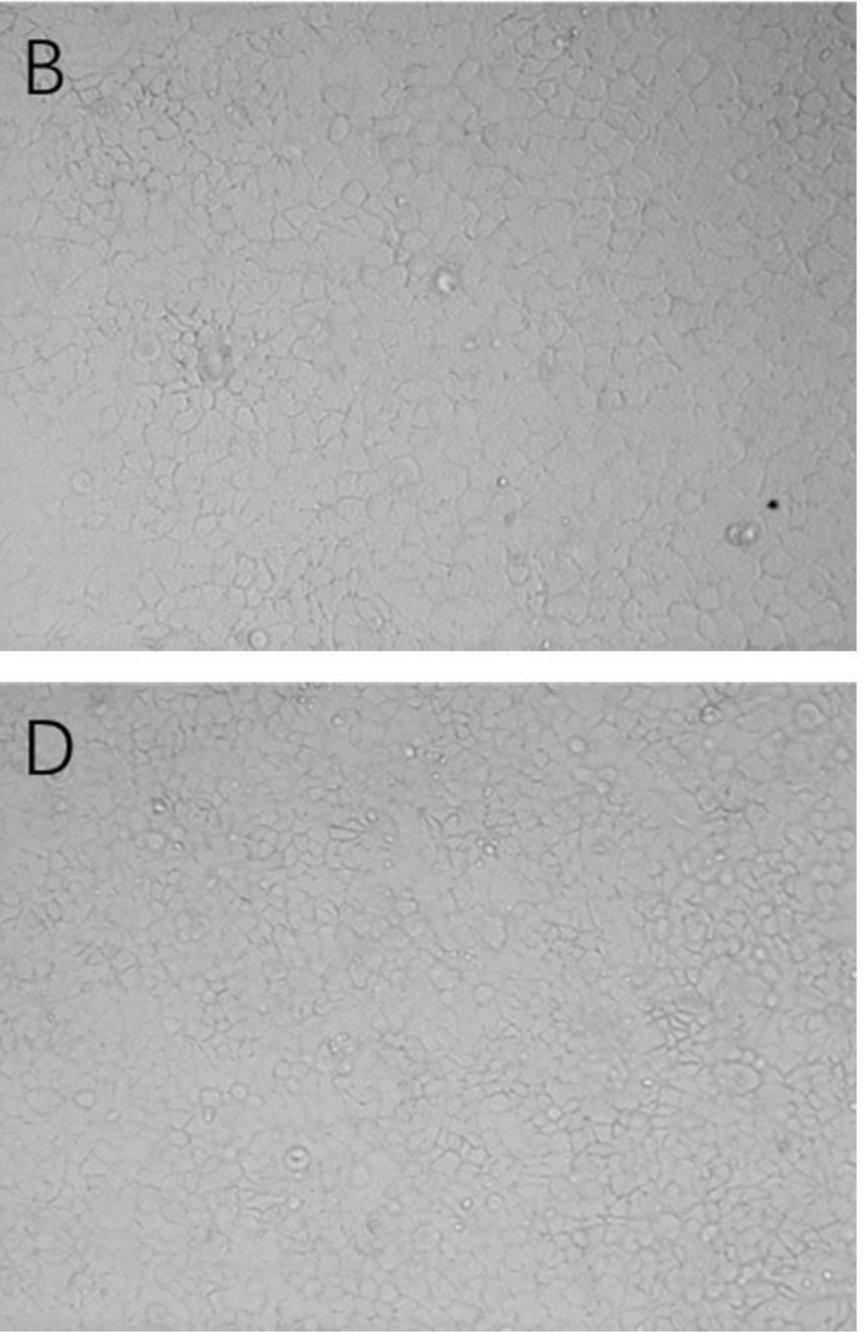

Figure 2. Effects of different concentration of 6-gingerol on growth of Caco-2 cells (200×). (A) Normal group; (B) 6-gingerol (50 $\mu$ g/mL) group; (C) 6-gingerol (100 $\mu \mathrm{g} / \mathrm{mL})$ group; (D) 6-gingerol $(150 \mu \mathrm{g} / \mathrm{mL})$ group.

Table 3. Effects of 6-gingerol on adhesive ability of Lactobacillus acidophilus with NCM460 cells.

\begin{tabular}{ccc}
\hline $\begin{array}{c}\text { Concentration } \\
\text { of 6-gingerol } \\
(\mu \mathrm{g} / \mathrm{mL})\end{array}$ & $\begin{array}{c}\text { Adhesive number } / \\
(\text { CFU/cell })\end{array}$ & Adhesive rate $\%)$ \\
\hline 0 & $0.722 \pm 0.009$ & $0.018 \pm 0.000$ \\
5 & $0.807 \pm 0.040^{\mathrm{bc}}$ & $0.020 \pm 0.001^{\mathrm{bc}}$ \\
10 & $0.885 \pm 0.052^{\mathrm{ab}}$ & $0.022 \pm 0.001^{\mathrm{ab}}$ \\
20 & $0.974 \pm 0.004^{\mathrm{a}}$ & $0.024 \pm 0.000^{\mathrm{a}}$ \\
\hline
\end{tabular}

Compared with control group, ${ }^{\mathrm{a}, \mathrm{b}, \mathrm{c}} \mathrm{P}<0.05$.
Table 4. Effects of 6-gingerol on adhesive ability of Bifidobacterium bifidum with NCM460 cells.

\begin{tabular}{ccc}
\hline $\begin{array}{c}\text { Concentration of } \\
\text { 6-gingerol }(\mu \mathrm{g} / \mathrm{mL})\end{array}$ & $\begin{array}{c}\text { Adhesive number } / \\
(\mathrm{CFU} / \text { cell })\end{array}$ & Adhesive rate $(\%)$ \\
\hline 0 & $2.676 \pm 0.021$ & $0.067 \pm 0.001$ \\
5 & $2.880 \pm 0.040^{\mathrm{c}}$ & $0.072 \pm 0.001^{\mathrm{c}}$ \\
10 & $3.325 \pm 0.005^{\mathrm{b}}$ & $0.083 \pm 0.000^{\mathrm{b}}$ \\
20 & $3.717 \pm 0.134^{\mathrm{a}}$ & $0.093 \pm 0.003^{\mathrm{a}}$ \\
\hline
\end{tabular}

Compared with control group, ${ }^{\mathrm{a}, \mathrm{b}, \mathrm{c}} \mathrm{P}<0.05$. 
6-gingerol $(5,10,20 \mu \mathrm{g} / \mathrm{mL}$ significantly increased the number of adherent probiotics Lactobacillus acidophilus and Bifidobacterium bifidum with NCM460 cells and the adhesion rate. The differences were significant $(\mathrm{P}<0.05)$. The results were showed in Tables 3 and 4. Addition of 6 -gingerol could promote the adhesion of these two probiotics strains to NCM460 cells in a dose-dependent manner.

Gram staining of probiotics adhering to colonic epithelial NCM460 cells were shown in Figure 3 and 4. Two kinds of probiotics (Lactobacillus acidophilus and Bifidobacterium bifidum) were multi-shaped or rod-shaped adherent on or around NCM460 cells. There had some cross-linkings between the cells. Compared with the normal group, the number of Lactobacillus acidophilus or Bifidobacterium bifidum attached to 6-gingerol treated-NCM460 cells significantly increased. This is consistent with the results of the adhesion count and adhesion rate in Table 3 and Table 4.

According to the previously reported (Volstatova et al., 2017), the adhesiveness of two potentially probiotic strains to epithelial cells was increased upon treatment with apple pulp extracts and apple phenolics, which strengthened the evidence for a new mechanism by which natural food products such as apple polyphenols affected the human microbiota. These findings were in accordance with our results.

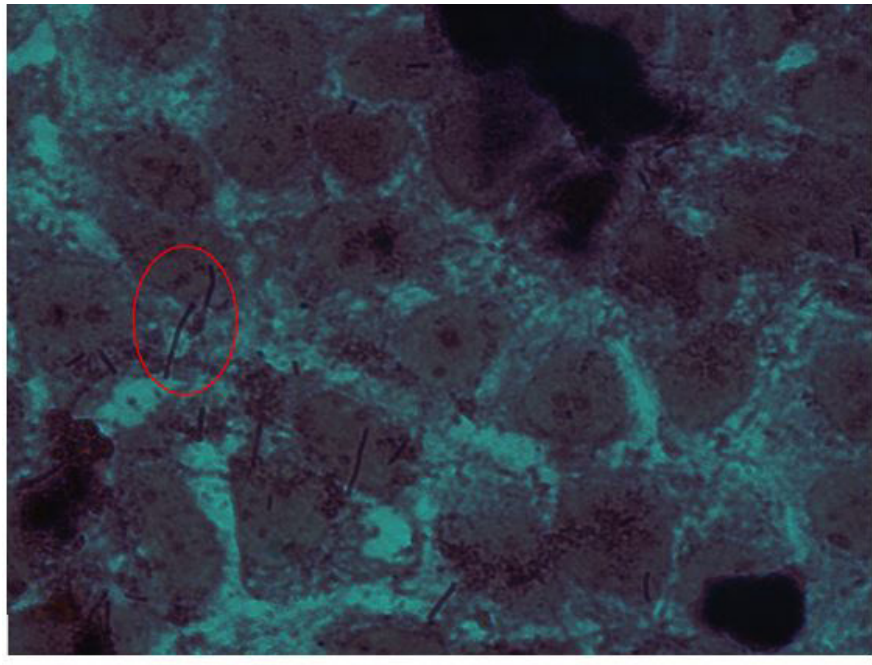

(a)

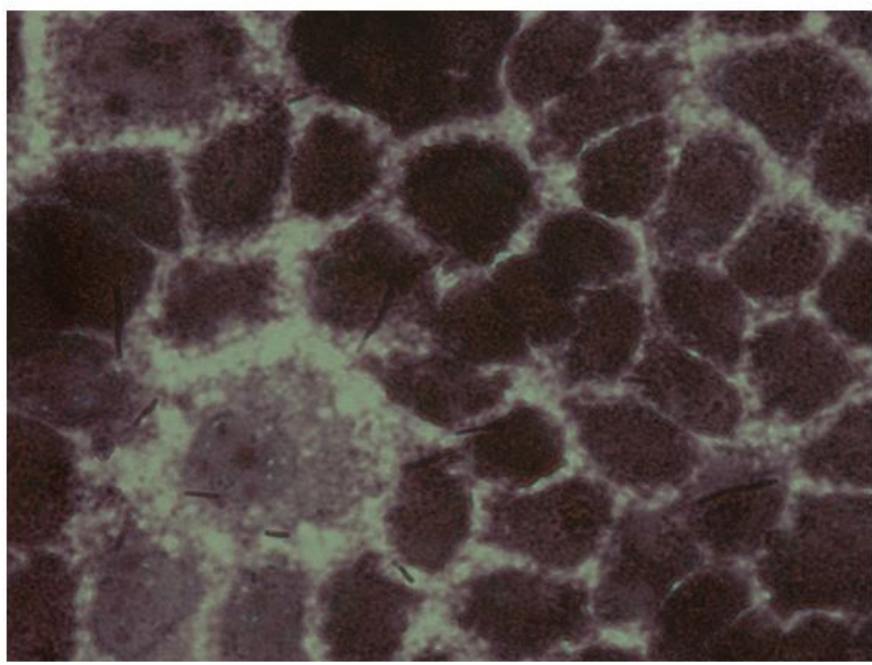

(c)

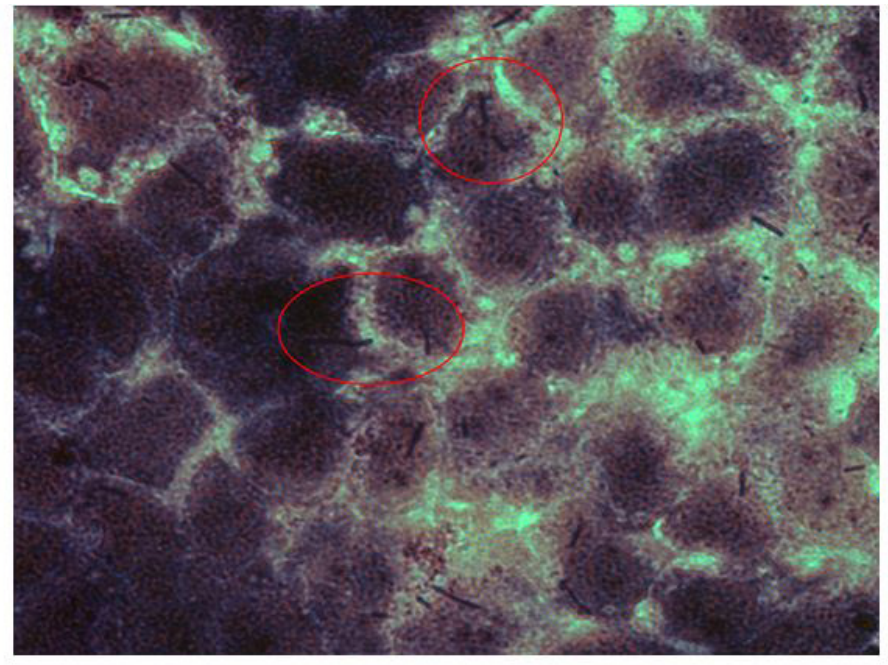

(b)

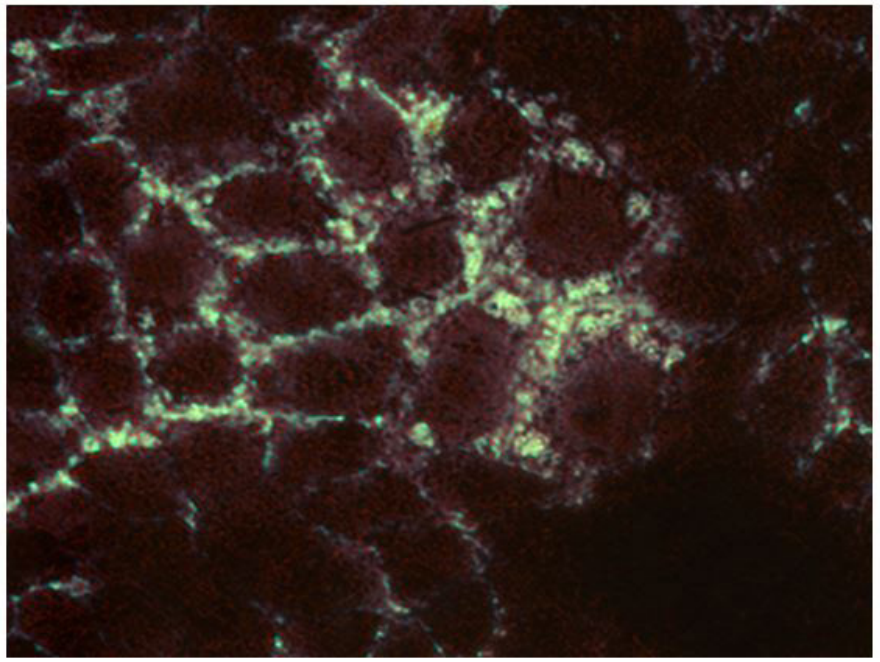

(d)

Figure 3. Effects of 6-gingerol on the adhesive ability of Lactobacillus acidophilus to NCM460 cells (Gram staining, 1000×). (a) Normal group; (b) 6-gingerol (5 $\mu \mathrm{g} / \mathrm{mL})$ group; (c) 6-gingerol (10 $\mu \mathrm{g} / \mathrm{mL})$ group; (d) 6-gingerol (20 $\mu \mathrm{g} / \mathrm{mL})$ group. 


\subsection{Promotive effect of 6-gingerol on adhesive ability of probiotics with Caco-2 cells}

The results were showed in Tables 5 and 6. Compared with the normal group, addition of 6-gingerol $(50,100$,
$150 \mu \mathrm{g} / \mathrm{mL}$ ) significantly increased the number of adherent probiotics with Caco- 2 cells and adhesive rate. The differences were significant $(\mathrm{P}<0.05)$. Results showed that addition of 6 -gingerol could promote the adhesion of Lactobacillus

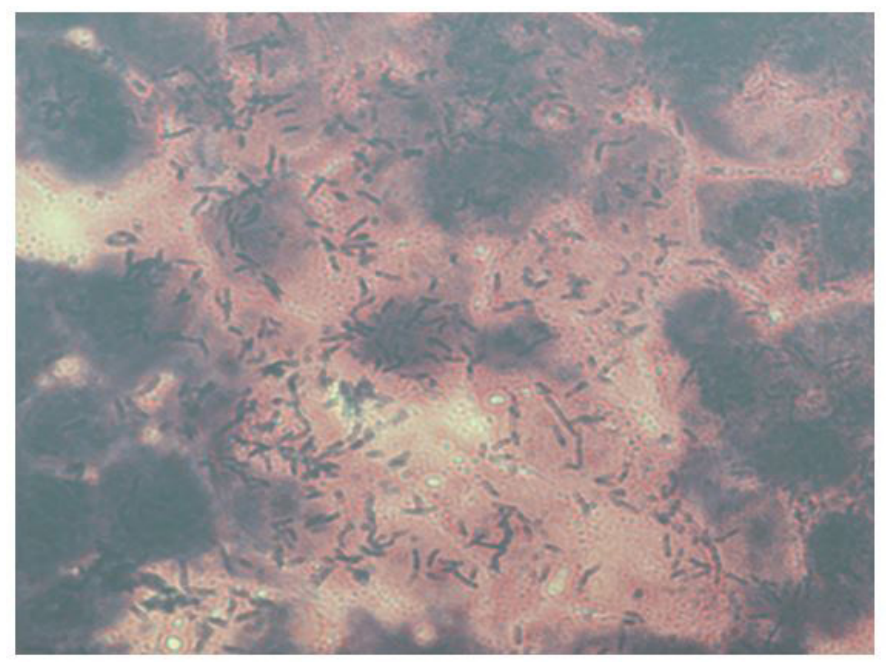

(a)

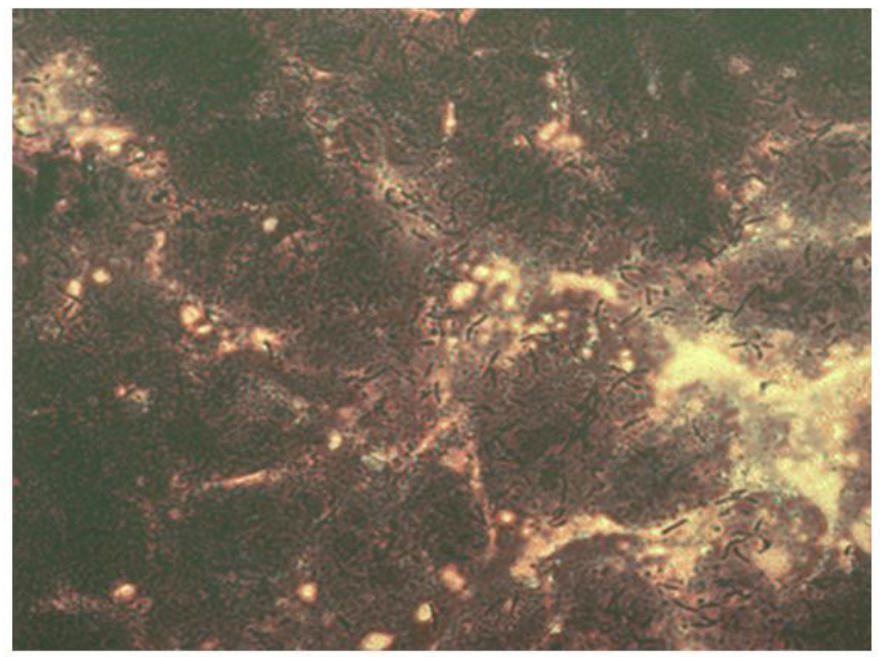

(c)

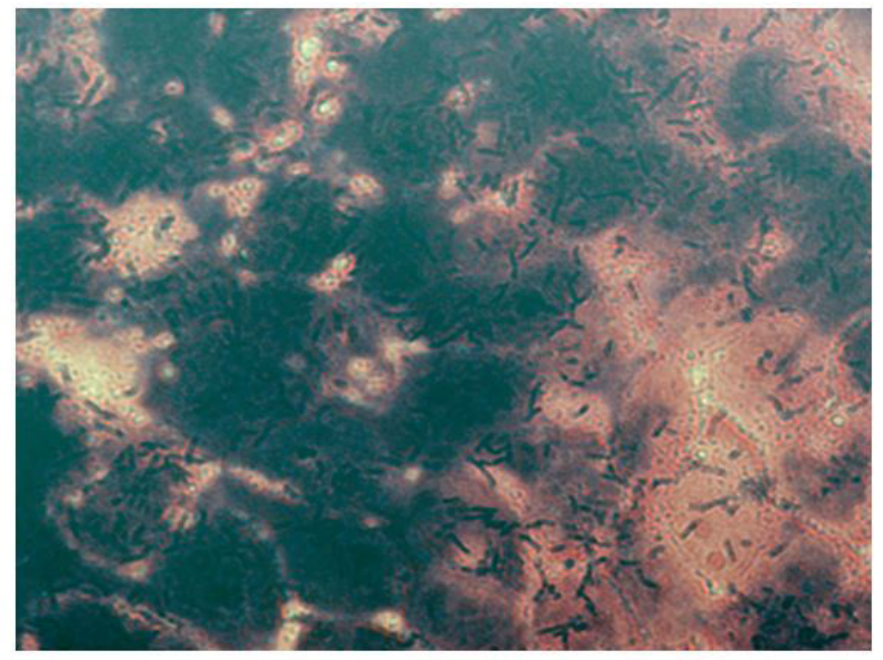

(b)

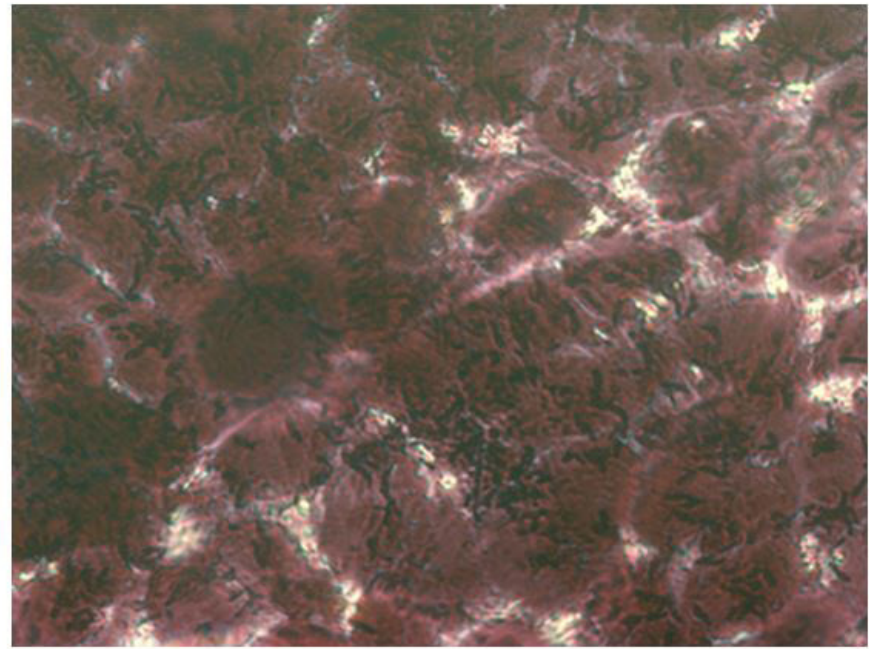

(d)

Figure 4. Effects of 6-gingerol on the adhesive ability of Bifidobacterium bifidum to NCM460 cells (Gram staining, 1000×). (a) Normal group; (b) 6-gingerol (5 $\mu \mathrm{g} / \mathrm{mL})$ group; (c) 6-gingerol (10 $\mu \mathrm{g} / \mathrm{mL})$ group; (d) 6-gingerol (20 $\mu \mathrm{g} / \mathrm{mL})$ group.

Table 5. Effect of 6-gingerol on adhesive ability of Lactobacillus acidophilus with Caco-2 cells.

\begin{tabular}{ccc}
\hline $\begin{array}{c}\text { Concentration of } \\
\text { 6-gingerol }(\mu \mathrm{g} / \mathrm{mL})\end{array}$ & $\begin{array}{c}\text { Adhesive number } / \\
(\text { CFU/cell })\end{array}$ & Adhesive rate $(\%)$ \\
\hline 0 & $7.099 \pm 0.016$ & $0.177 \pm 0.000$ \\
50 & $8.103 \pm 0.063^{\mathrm{c}}$ & $0.203 \pm 0.001^{\mathrm{c}}$ \\
100 & $9.145 \pm 0.115^{\mathrm{b}}$ & $0.229 \pm 0.003^{\mathrm{b}}$ \\
150 & $10.400 \pm 0.014^{\mathrm{a}}$ & $0.260 \pm 0.004^{\mathrm{a}}$ \\
\hline
\end{tabular}

Compared with control group, ${ }^{\mathrm{a}, \mathrm{b}, \mathrm{c}} \mathrm{P}<0.05$.
Table 6. Effect of 6-gingerol on adhesive ability of Bifidobacterium bifidum with Caco-2 cells.

\begin{tabular}{ccc}
\hline $\begin{array}{c}\text { Concentration of } \\
\text { 6-gingerol }(\mu \mathrm{g} / \mathrm{mL})\end{array}$ & $\begin{array}{c}\text { Adhesive number } / \\
(\mathrm{CFU} / \text { cell })\end{array}$ & Adhesive rate (\%) \\
\hline 0 & $9.114 \pm 0.081$ & $0.228 \pm 0.002$ \\
50 & $12.216 \pm 0.141^{\mathrm{c}}$ & $0.305 \pm 0.003^{\mathrm{c}}$ \\
100 & $13.330 \pm 0.077^{\mathrm{b}}$ & $0.333 \pm 0.002^{\mathrm{b}}$ \\
150 & $13.980 \pm 0.063^{\mathrm{a}}$ & $0.350 \pm 0.001^{\mathrm{a}}$ \\
\hline
\end{tabular}

Compared with control group, ${ }^{\mathrm{a}, \mathrm{b}, \mathrm{c}} \mathrm{P}<0.05$. 


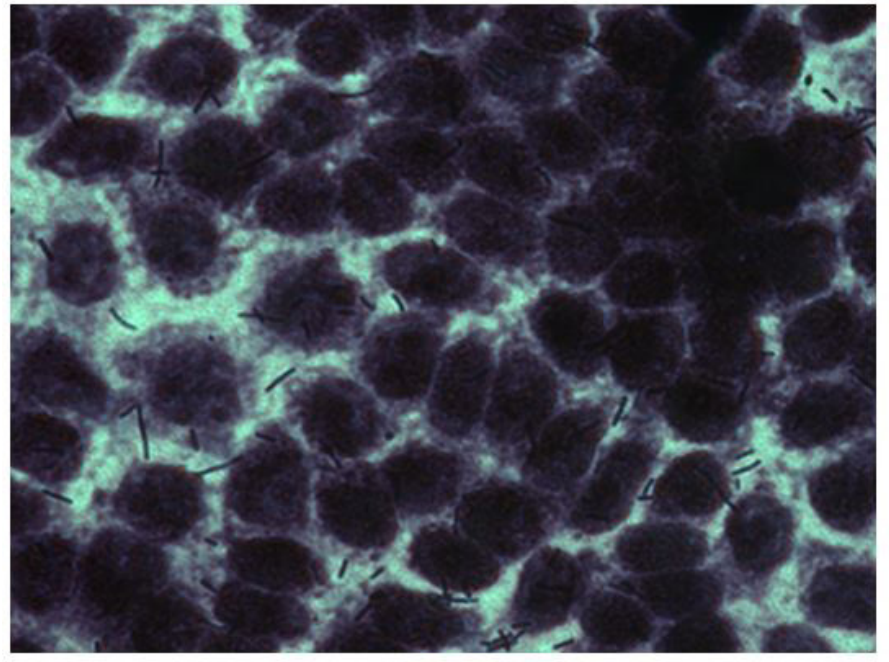

(a)

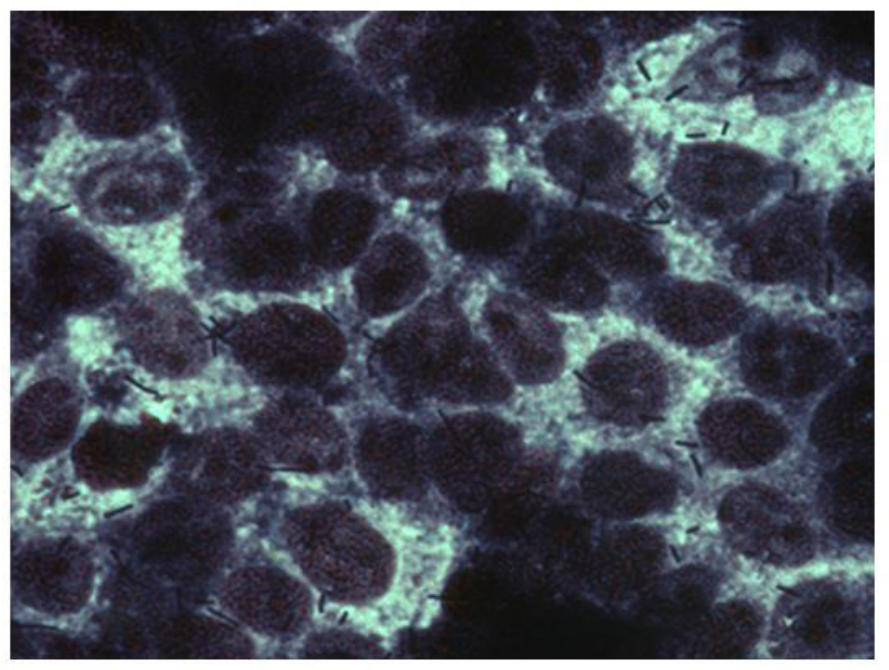

(c)

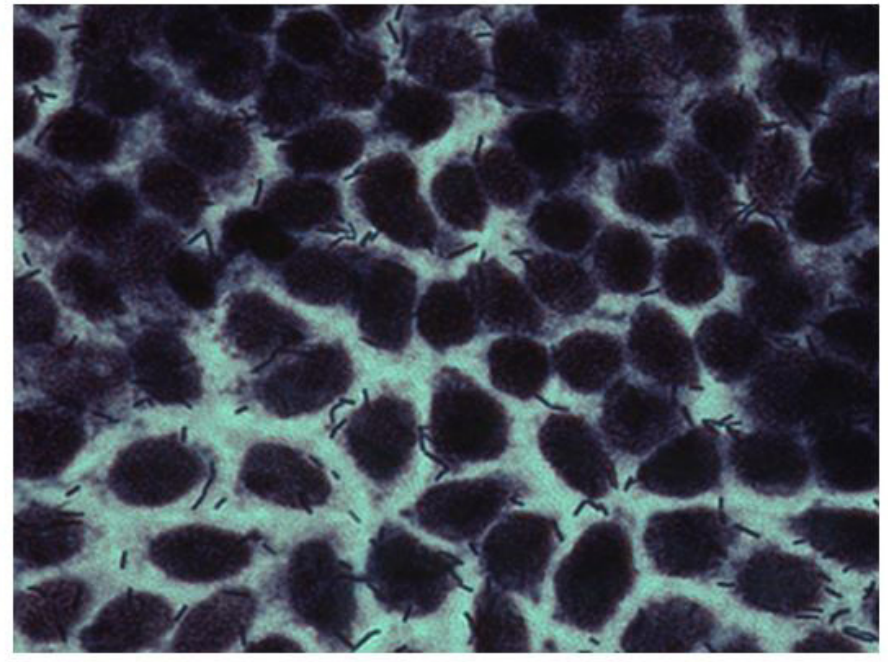

(b)

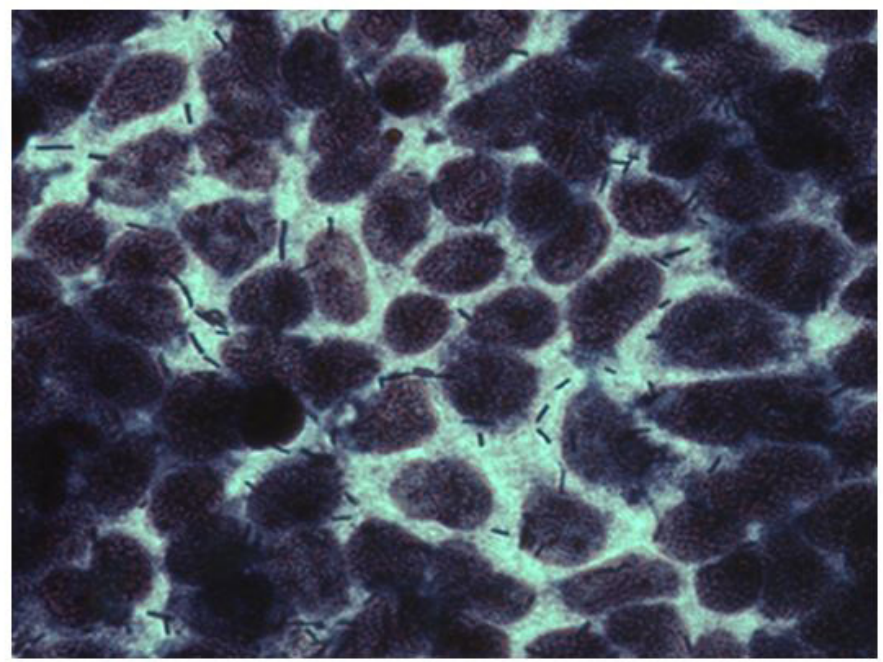

(d)

Figure 5. Effects of 6-gingerol on the adhesive ability of Lactobacillus acidophilus to Caco-2 cells (Gram staining, 1000×). (a) Normal group; (b) 6-gingerol (50 $\mu \mathrm{g} / \mathrm{mL})$ group; (c) 6-gingerol (100 $\mu \mathrm{g} / \mathrm{mL})$ group; (d) 6-gingerol (150 $\mu \mathrm{g} / \mathrm{mL})$ group.

acidophilus and Bifidobacterium bifidum to Caco-2 cells in a dose-dependent manner.

Gram staining of probiotics adhering to colonic epithelial Caco-2 cells were showed in Figure 5 and Figure 6. Two kinds of probiotics (Lactobacillus acidophilus and Bifidobacterium bifidum) were all nearly adhered to Caco-2 cells. Compared with the normal group, the number of Lactobacillus acidophilus or Bifidobacterium bifidum attached to 6-gingerol treated-Caco-2 cells significantly increased in a dose-dependent (Figure 5, Figure 6). This is consistent with the results of the adhesive count and adhesive rate in Table 5 and Table 6.

Previously reports assessed the influence of polyunsaturated fatty acids (PUFA, linoleics, arachidonic, and docosahexaenoic acids) at physiological concentrations in the growth media on the growth and adhesion of probiotics Lactobacillus $G G$ and Lactobacillus casei Shirota, which indicated that the action of probiotics in the gut may be modulated by dietary PUFA (Kankaanpää et al., 2001). These findings confirmed the present research, which indicated the adhesion to mucosal surfaces being pivotal in health promoting effects by probiotics. 


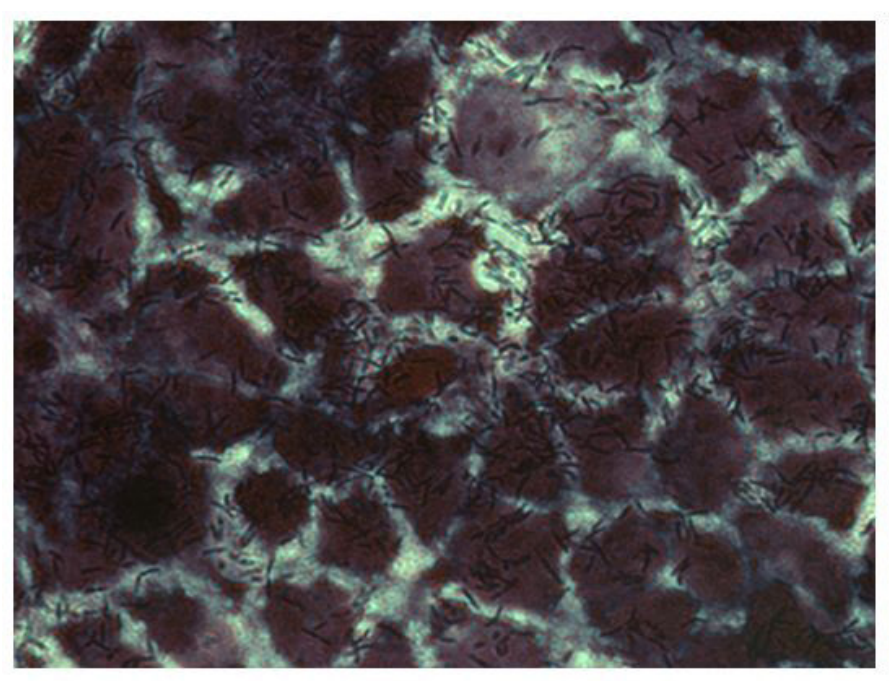

(a)

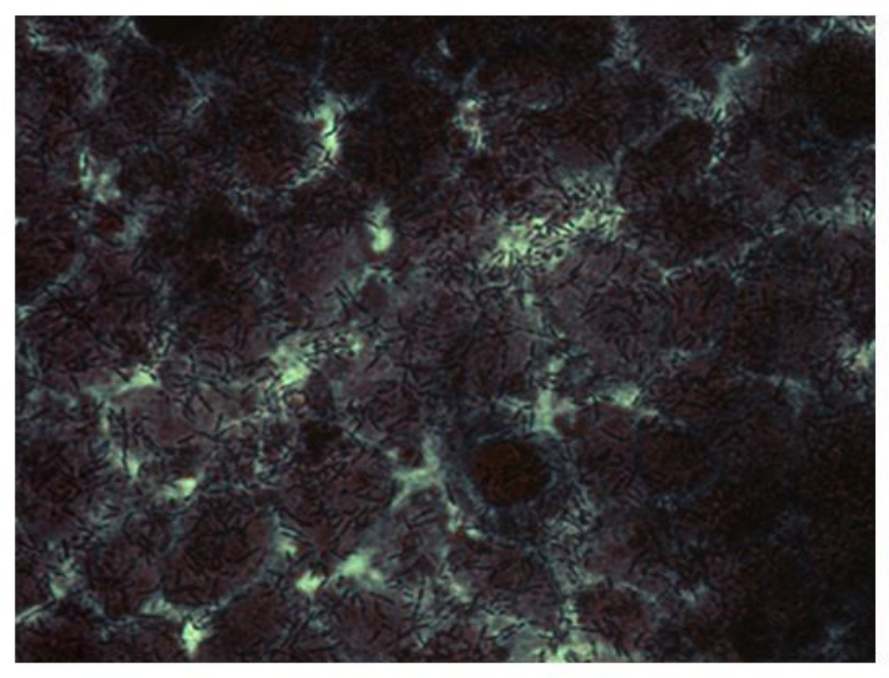

(c)

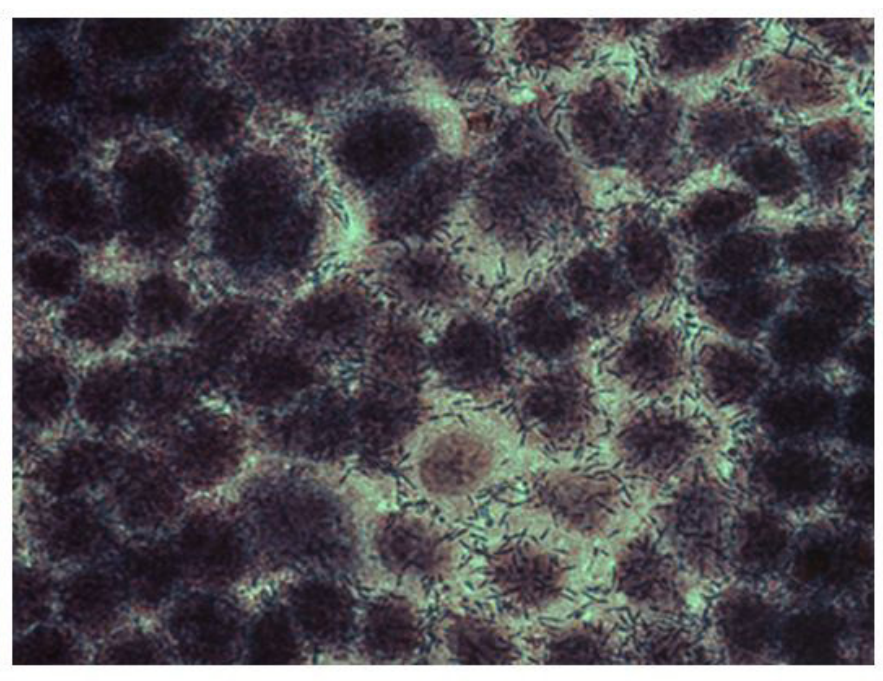

(b)

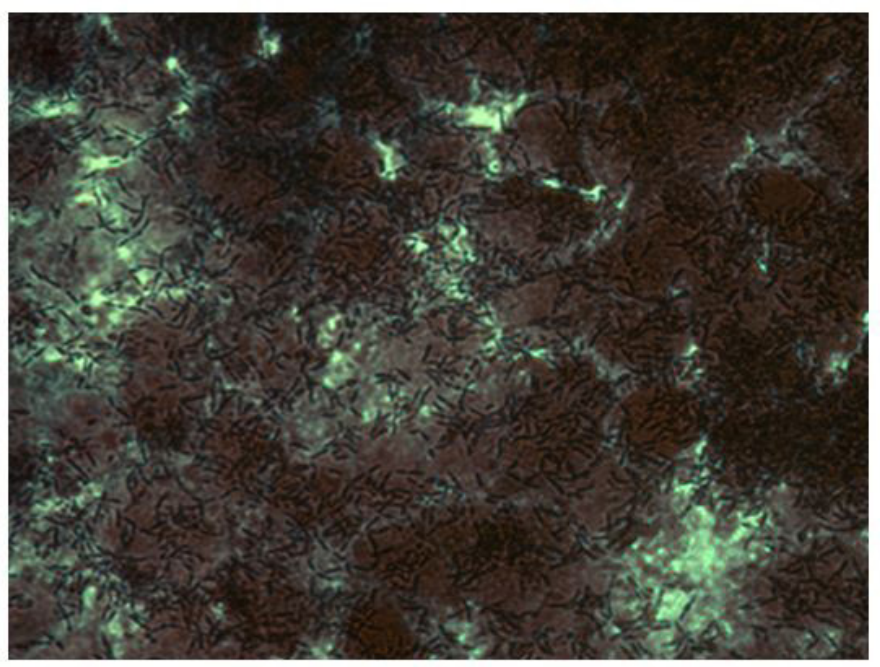

(d)

Figure 6. Effects of 6-gingerol on the adhesive ability of Bifidobacterium bifidum to Caco-2 cells (Gram staining, 1000×). (a) Normal group; (b) 6-gingerol (50 $\mu \mathrm{g} / \mathrm{mL})$ group; (c) 6-gingerol (100 $\mu \mathrm{g} / \mathrm{mL})$ group; (d) 6-gingerol (150 $\mu \mathrm{g} / \mathrm{mL})$ group.

\section{Conclusion}

The effects of 6-gingerol on adhesive promotion of probiotics to colonic epithelial cells were investigated. 6-gingerol had no damage to colonic epithelial cells within a certain range of concentration. 6-gingerol promoted the adhesion of probiotics (lactophilus acidophilus and bifidobacterium bifidum) to colonic epithelial cells (NCM460 cells and Caco-2 cells) in a dose-dependent manner. These suggested that 6-gingerol can promote healthy function of probiotics and make them exert probiotic activity continuously. Further investigations of 6-gingerol on the improvement of intestinal micro-ecosystem would be done in the future studies.

\section{Acknowledgements}

This work was supported by National Natural Science Foundation of China (Grant No. 31872899), Key University Natural Science Research Project of Jiangsu Province (Grant No. 16KJA550001), and the Priority Academic Program Development of Jiangsu Higher Education Institutions (PAPD).

\section{References}

Ajayi, B. O., Adedara, I. A., \& Farombi, E. O. (2018). Protective mechanisms of 6-gingerol in dextran sulfate sodium-induced chronic ulcerative colitis in mice. Human and Experimental Toxicology, 37(10), 10541068. http://dx.doi.org/10.1177/0960327117751235. PMid:29350052. 
Bai, J., Li, W. F., Hang, Q., Cui, Z. W., Yu, D. Y., \& Huang, Y. (2012). Effects of several probiotics on adhesion to caco-2 cells and pathogenic bacteria. Acta Zoonutrimenta Sinica, 24(10), 1992-1998. http:// dx.doi.org/10.3969/j.issn.1006-267x.2012.10.019.

Bao, Y., Zhang, Y., Zhang, Y., Liu, Y., Wang, S., Dong, X., Wang, Y., \& Zhang, H. (2010). Screening of potential probiotic properties of Lactobacillus fermentum isolated from traditional dairy products. Food Control, 21(5), 695-701. http://dx.doi.org/10.1016/j.foodcont.2009.10.010.

Choi, J. G., Kim, S. Y., Jeong, M., \& Oh, M. S. (2018). Pharmacotherapeutic potential of ginger and its compounds in age-related neurological disorders. Pharmacology \& Therapeutics, 182, 56-69. http://dx.doi. org/10.1016/j.pharmthera.2017.08.010. PMid:28842272.

Gopal, P. K., Prasad, J., Smart J., \& Gill, H. S. (2001). In vitro adherence properties of Lactobacillus rhamnosus DR20 and Bifidobacterium lactis DR10 strains and their antagonistic activity against an enterotoxigenic Escherichia coli. International Journal of Food Microbiology, 67(3), 207-216. http://dx.doi.org/10.1016/s01681605(01)00440-8. PMID: 11518430.

Huang, Y., Zhou, X., Wang, G., Kuang, Z., Zhao, H., Mo, W., \& Cao, J. (2014). Effects of 5 lactic acid bacteria on immunity and disease resistance of onil tilapia. Fisheries Science, 33(10), 601-605. http:// dx.doi.org/10.3969/j.issn.1003-1111.2014.10.001.

Kankaanpää, P. E., Salminen, S. J., Isolauri, E., \& Lee, Y. K. (2001). The influence of polyunsaturated fatty acids on probiotic growth and adhesion. FEMS Microbiology Letters, 194(2), 149-153. http:// dx.doi.org/10.1111/j.1574-6968.2001.tb09460.x. PMid:11164299.

Kotzamanidis, C., Kourelis, A., Litopoulou-Tzanetaki, E., Tzanetakis, N., \& Yiangou, M. (2010). Evaluation of adhesion capacity, cell surface traits and immunomodulatory activity of presumptive probiotic Lactobacillus strains. International Journal of Food Microbiology, 140(2-3), 154-163. http://dx.doi.org/10.1016/j.ijfoodmicro.2010.04.004. PMid:20452079.

Li, P., Yin, Y., Yu, Q., \& Yang, Q. (2011). Lactobacillus acidophilus S-layer protein-mediated inhibition of Salmonella-induced apoptosis in Caco-2 cells. Biochemical and Biophysical Research Communications, 409(1), 142-147. http://dx.doi.org/10.1016/j.bbrc.2011.04.131. PMid:21557929.

Li, Y., Xu, B., Xu, M., Chen, D., Xiong, Y., Lian, M., Sun, Y., Tang, Z., Wang, L., Jiang, C., \& Lin, Y. (2017). 6-Gingerol protects intestinal barrier from ischemia/reperfusion-induced damage via inhibition of p38 MAPK to NF- $\kappa B$ signalling. Pharmacological Research, 119, 137148. http://dx.doi.org/10.1016/j.phrs.2017.01.026. PMid:28167239.

Liu, D., Jiang, X. Y., Zhou, L. S., Song, J. H., \& Zhang, X. (2016). Effects of probiotics on intestinal mucosa barrier in patients with colorectal cancer after operation: meta-analysis of randomized controlled trials. Medicine, 95(15), e3342. http://dx.doi.org/10.1097/ MD.0000000000003342. PMid:27082589.
Liu, X., Liu, W., Zhang, Q., Tian, F., Wang, G., Zhang, H., \& Chen, W. (2013). Screening of lactobacilli with antagonistic activity against enteroinvasive Escherichia coli. Food Control, 30(2), 563-568. http:// dx.doi.org/10.1016/j.foodcont. 2012.09.002.

Majdoub, Y. O. E., Diouri, M., Arena, P., Arigò, A., Cacciola, F., Rigano, F., Dugo, P., \& Mondello, L. (2019). Evaluation of the availability of delphinidin and cyanidin-3-O-sambubioside from Hibiscus sabdariffa and 6-gingerol from Zingiber officinale in colon using liquid chromatography and mass spectrometry detection. European Food Research and Technology, 245(11), 2425-2433. http://dx.doi. org/10.1007/s00217-019-03358-1.

Prakasita, V. C., Asmara, W., Widyarini, S., \& Wahyuni, A. E. T. H. (2019). Combinations of herbs and probiotics as an alternative growth promoter: an in vitro study. Veterinary World, 12(4), 614-620. http://dx.doi.org/10.14202/vetworld.2019.614-620. PMid:31190720.

Rahmani, A. H., Shabrmi, F. M., \& Aly, S. M. (2014). Active ingredientsof ginger as potential candidates in the prevention and treatment of diseases via modulation of biological activities. International Journal of Physiology, Pathophysiology and Pharmacology, 6(2), 125-136. http://dx.doi.org/10.1098/ rspb.2011.0652. PMid:25057339.

Vázquez-Fresno, R., Llorach, R., Marinic, J., Tulipani, S., Garcia-Aloy, M., Espinosa-Martos, I., Jiménez, E., Rodríguez, J. M., \& Andres-Lacueva, C. (2014). Urinary metabolomic fingerprinting after consumption of a probiotic strain in women with mastitis. Pharmacological Research, 87, 160-165. http://dx.doi.org/10.1016/j.phrs.2014.05.010. PMid:24880136.

Volstatova, T., Marsik, P., Rada, V., Geigerova, M., \& Havlik, J. (2017). Effect of apple extracts and selective polyphenols on the adhesion of potential probiotic strains of Lactobacillus gasseri $\mathrm{R}$ and Lactobacillus casei FMP. Journal of Functional Foods, 35, 391-397. http://dx.doi. org/10.1016/j.jff.2017.06.005.

Wang, T., Chun, L., Li, J., Du, P., Liu, L., Xu, Z., \& Yang, Y. (2019). Effect of ethanol stress on membrane physiology and adhesion of lactobacillus plantarum. Shipin Kexue, 40(18), 63-69. http://dx.doi. org/10.7506/spkx1002-6630-20181009-059.

Zhang, H. (2019). Probiotics, gut microbes and health. Science China Press, 64(3), 245.

Zhu, Y., Wang, F., Zhao, Y., Wang, P., \& Sang, S. (2017). Gastroprotective [6]-gingerol aspirinate as a novel chemopreventive prodrug of aspirin for colon cancer. Scientific Reports, 7(1), 40119. http://dx.doi. org/10.1038/srep40119. PMid:28067282.

Zhu, Y., Yin, M., \& Wei, Y. (2019). Effect of fermented juices of fruits and vegetables on the adhesion of intestinal probiotics and Escherichia coli. Food Science and Technology (Campinas), 44(11), 9-15. http:// dx.doi.org/10.13684/j.cnki.spkj.2019.11.003. 